\title{
IMPROVEMENT OF INTEGRATED ENTERPRISE MANAGEMENT SYSTEMS
}

\section{УДОСКОНАЛЕННЯ ІНТЕГРОВАНИХ СИСТЕМ УПРАВЛІННЯ ПІДПРИЕМСТВАМИ}

\section{Heorhiadi Nelli ${ }^{1}$ \\ Pavlenko Olena ${ }^{2}$}

DOI: https://doi.org/10.30525/978-9934-571-78-7_3

\begin{abstract}
Ways to improve the management of integrated enterprise management systems are substantiated. The author's conclusions and proposals are scientifically substantiated methodological tools for implementing the system of enterprise goals, overcoming the features of entropy, and achieving a higher level of competitiveness. Application of these tools allows executives, image-makers, marketers, and other subjects of enterprise management to select and realize such tactics of achieving goals that are characterized by creativity, rationality, consistency with the goals of higher order in space and time. It is proved that integrated enterprise management systems should be based on functional and technological structure. This very structure is the basis for creating highly integrated management systems. Structural and functional analysis of existing management systems allowed drawing conclusions that the formation and use of integrated management systems need to be carried out based on a number of principles, namely: completeness of information support; adaptation to the needs, style, and methods of a particular manager; direct participation of managers of all levels in the development of an integrated management system; information independence and information equality of the subjects of management; information security; economic efficiency; technological capacity; systemacity; targeting; target result. Their observance by heads of departments, engineers, technologists, marketers,
\end{abstract}

\footnotetext{
${ }^{1}$ Doctor of Economic Sciences, Professor,

Professor at Department of Management and International Entrepreneurship,

Lviv Polytechnic National University, Ukraine

${ }^{2}$ Candidate of Economic Sciences, Associate Professor,

Head of Department of Environmental Management,

Odessa State Environmental University, Ukraine
} 


\section{Chapter «Economic sciences»}

etc. enables rationalization of managerial decisions on balancing the parameters that characterize the state of the management system.

\section{1. Ветуп}

Незважаючи на те, що тисячі вітчизняних підприємств належать до різноманітних інтегрованих структур, синергічні ефекти від їхньої діяльності $є$ невисокими. Системи управління учасників цих інтегрованих утворень $\epsilon$ нераціональними, виробничий потенціал більшості крупних підприємств не тільки не відтворюється, а й знижується. Як наслідок, вітчизняні споживачі промислової продукції імпортують ії з-за кордону. 3 метою подолання деструктивних економічних явищ і процесів у промисловості необхідним є створення систем управління, які б враховували такі особливості вітчизняних промислових підприємств, як кількість i складність технологічних процесів виробництва, багатономенклатурність використовуваних матеріалів і готової продукції, територіальну розгалуженість структурних підрозділів, об'ємність і диверсифікованість масивів даних щодо працівників і бізнес-партнерів, об'єктів фінансового, управлінського і статистичного обліку тощо. Виконання цього завдання націлене на інтеграцію локальних підсистем управління на засадах упровадження високоавтоматизованих інформаційних систем, що забезпечить промисловим підприємствам посилення конкурентних позицій, підвищення інвестиційної привабливості, зростання рівня економічного розвитку. Проблема полягає у відсутності концептуальних, теоретико-методологічних та методико-прикладних положень із формування і використання інтегрованих систем управління підприємств (ІСУП).

\section{2. Аналіз ефективності інтегрованих систем управління}

Удосконаленню будь-якого об’єкта передує визначення напрямів удосконалення. У результаті дослідження сутності та особливостей моніторингу стану ІСУП виявлено, що напрямами удосконалення досліджуваного об'єкта є інформаційний супровід підприємств ІСУП.

Інформаційний супровід ІСУП є системою якісних і кількісних показників, що характеризують відповідність параметрів використовуваної підприємством інтегрованої системи управління потребам користувачів і критеріям економічної ефективності системи. Ці показники відображають рівень реалізації організацією встановлених цілей, якісний і кількісний склад суб'єктів управлінської діяльності, розви- 
неність системи документального оформлення виробничо-господарських операцій організації, забезпеченість керівників підприємства управлінською інформацією та інформаційними технологіями. Загалом, за значенням узагальнюючого показника інформаційного супроводу ІСУП можна робити висновок про рівень задоволення управ-

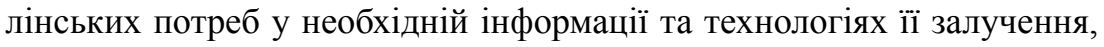
обробки, зберігання і використання. Удосконалення рівня інформаційного супроводу ІСУП має на меті підвищити рівень: реалізації організацією цілей; інформаційної освіти та кваліфікації працівників; забезпеченості підрозділів організації фахівцями 3 обслуговування використовуваної інформаційної системи; розвитку системи документоутворення та документообігу в організації; задоволення управлінських потреб у необхідній управлінській інформації та інформаційних технологіях, а також безпечності їхнього використання тощо.

Під час формування моделі ІСУП одним із етапів $є$ створення системи їі цілей. Стратегічна мета розроблення ІСУП полягає в оптимізації витрат коштів, часу та інтелектуальних витрат на управління підприємством, супроводу його економічного розвитку. Узгодженість цілей у системі управління економічним розвитком, їхня реалістичність і конкретність $є$ передумовою успішного функціонування ІСУП і їі підсистеми, зокрема. Супровід цих умов вимагає безперервного моніторингу стану реалізації цілей, оцінювання їхньої актуальності, потреби заміни цілей іншими або прискорення їхньої реалізації тощо. Рівень реалізації цілей ICУП, як і цілей організації загалом, значною мірою залежить від рівня трудової дисципліни в організації, адже досягнення більшості цілей вимагає виконання низки завдань різними групами працівників підприємства та керівників різних рівнів управління. Несвоєчасне і неповне виконання завдань, як відомо, може призвести до порушення технологічного процесу, до розірвання укладених договорів, до погіршення морально-психологічного клімату в організації. Рівень трудової дисципліни i, відповідно, рівень своєчасності і повноти виконання завдань на підприємстві тісно пов'язані з рівнем інформаційної освіти працівників підприємства та достатньою їхньою кількістю.

За результатами експертного дослідженнями, яке здійснювалось на базі промислових підприємств, виявлено, що упродовж аналізованого періоду постійно зростала частка осіб, що володіють спеціальною інформаційною освітою. Дослідники виявили також те, що протягом 


\section{Chapter «Economic sciences»}

2009-2018 рр. постійно збільшувалась кількість користувачів персональними комп'ютерами на підприємствах, проте частка тих користувачів, що не мають спеціальної інформаційної освіти, постійно зменшувалась. Ця тенденція характерна для керівників підприємств, а також для службовців та робітників (табл. 1).

Рівень інформаційного супроводу ІСУП характеризує також документальне забезпечення управлінської діяльності підприємства. Важливість цього елемента інформаційного супроводу пов'язана з тим, що сьогодні більшість фахівців достовірною інформацію вважають ту, яка $\epsilon$ документально підтвердженою. Від рівня організації документообігу на підприємстві значною мірою залежить успішність розроблення і реалізації управлінських рішень, а також ефективність комунікацій.

Таблиця 1

\section{Рівень інформаційної освіченості працівників досліджуваних підприємств}

\begin{tabular}{|c|c|c|c|c|c|}
\hline \multirow{2}{*}{\begin{tabular}{c} 
Роки \\
\cline { 3 - 6 } \\
\cline { 3 - 6 }
\end{tabular}} & $\begin{array}{c}\text { Керівники } \\
\text { вищого рівня } \\
\text { управління }\end{array}$ & $\begin{array}{c}\text { Керівники } \\
\text { середнього } \\
\text { рівня } \\
\text { управління }\end{array}$ & $\begin{array}{c}\text { Керівники } \\
\text { низового рівня } \\
\text { управління }\end{array}$ & $\begin{array}{c}\text { Службовці і } \\
\text { робітники }\end{array}$ \\
\hline \multirow{2}{*}{1} & 2009 & 64 & 61 & 42 & 24 \\
\cline { 2 - 6 } & 2018 & 94 & 132 & 73 & 35 \\
\hline \multirow{2}{*}{2} & 2009 & 0 & 12 & 17 & 0 \\
\cline { 2 - 6 } & 2018 & 18 & 54 & 38 & 8 \\
\hline \multirow{2}{*}{3} & 2009 & 0 & 31 & 0 & 23 \\
\cline { 2 - 6 } & 2018 & 9 & 55 & 16 & 22 \\
\hline \multirow{2}{*}{4} & 2009 & 121 & 176 & 85 & 54 \\
\cline { 2 - 6 } & 2018 & 147 & 203 & 204 & 216 \\
\hline \multirow{2}{*}{5} & 2009 & 93 & 36 & 81 & 192 \\
\cline { 2 - 6 } & 2018 & 102 & 89 & 169 & 213 \\
\hline
\end{tabular}

Примітки: 1 - кількість суб' єктів систем комунікаційного менеджменту, які отримали спеціальну інформаційну освіту; 2 - кількість суб'єктів систем комунікаційного менеджменту, які пройшли або проходять курси підвищення кваліфікації; 3 - кількість суб'єктів систем комунікаційного менеджменту, які здобувають спеціальну інформаційну освіту; 4 - кількість суб'єктів систем комунікаційного менеджменту, які не мають спеціальної інформаційної освіти але $\epsilon$ користувачами персональних комп'ютерів; 5 - кількість суб'єктів систем комунікаційного менеджменту, які не мають спеціальної інформаційної освіти і не $є$ користувачами персональних комп'ютерів 
Систему документоутворення і документообігу необхідно удосконалювати на предмет супроводу: фізичної наявності документів, їхньої легітимності, повноти документування виробничо-господарських процесів в організації, правильності та безпечності оформлення і зберігання документів.

Щодо управлінської інформації та інформаційних технологій як сутнісних характеристик інформаційного супроводу ІСУП, то метою їхньог удосконалення є забезпечення: легітимності використання інформаційних технологій; наявності та відповідності інформаційних технологій управлінським потребам; безпечності використання інформаційних технологій; наявності, доступності, повноти, достовірності та своєчасності управлінської інформації тощо.

Серед напрямів удосконалення ІСУП виділено також економічну ефективність ІСУП. Більшість розробників і користувачів високоінтегрованих систем управління, що створені за допомогою впровадження високоавтоматизованого інформаційного супроводу ІСУП, вважають проблематичними забезпечення економічної ефективності інтегрованих систем і підтримку їхньої постійної відповідності управлінським потребам. Причинами цього є: по-перше, рівень економічної ефективності ІСУП здебільшого оцінюється за допомогою методів оцінювання ефективності інвестицій. 3 огляду на це, передумовою підвищення ефективності вкладень коштів у розвиток ІСУП $\epsilon$ зниження капітальних і поточних витрат. Для більшості підприємств прямого зв'язку між витратами на розвиток інтегрованої системи управління і доходами організації не встановлено. По-друге, швидке прогресування інформаційних технологій і постійне зростання потреб в оновленні управлінської інформації та застосовуваних програмних продуктах вимагає постійних витрат на удосконалення використовуваних автоматизованих систем управління. Загалом, це приводить до того, що підприємства, фінансовий успіх яких істотно залежить від наявності у них сучасних інформаційних технологій, а також від наявності висококваліфікованих працівників, можуть дозволити собі інвестувати кошти у розвиток ІСУП, оскільки зрештою ці кошти окуповуються. Своєю чергою, підприємства, керівники яких не здатні використовувати інформаційні технології та управлінську інформацію, залучену за їхньою допомогою для активізування діяльності і покращання фінансових результатів, не інвестують коштів 
у розвиток використовуваних ІСУП, оскільки вважають ці витрати непродуктивними.

Виконані дослідження показали, що незалежно від того, до якої групи належить підприємство, удосконалювати ІСУП необхідно, раціоналізуючи витрати на іiї формування і використання. На рис. 1 показано графічну залежність між рівнем економічної ефективності ІСУП та рівнем інформаційного супроводу ICУП. Зона «Z1» репрезентує стан системи, за якого рівень іiі економічної ефективності та рівень інформаційного супроводу $є$ прийнятними, тобто показник приросту рівня економічної ефективності більший від середньоринкового значення, а значення узагальнюючого показника рівня інформаційного супроводу лежить в інтервалі від 0,081 до 1. Ідентифікувавши такий стан інтегрованої системи управління, бачимо, що потреба у розробленні і реалізації рішень, націлених на його покращання, відсутня. Близьким до цього стану можна вважати також стан системи, за якого $P_{y}$ лежить у інтервалі від 0,081 до 1 , а значення $E_{p}=\overline{E_{p}}$.

Своєю чергою, стан інтегрованої системи управління у зоні « $\mathrm{Z}_{9} »$ спонукає до пошуку шляхів підвищення рівня економічної ефективності використовуваної інтегрованої системи управління.

Достатньо прийнятним є також стан ІСУП, який належить до зони «Z $Z_{2}$. Його ідентифікація засвідчує високий рівень економічної ефективності ІСУП та незначну невідповідність параметрів ІСУП потребам користувачів. 3 огляду на це, його ідентифікування вимагає розроблення i

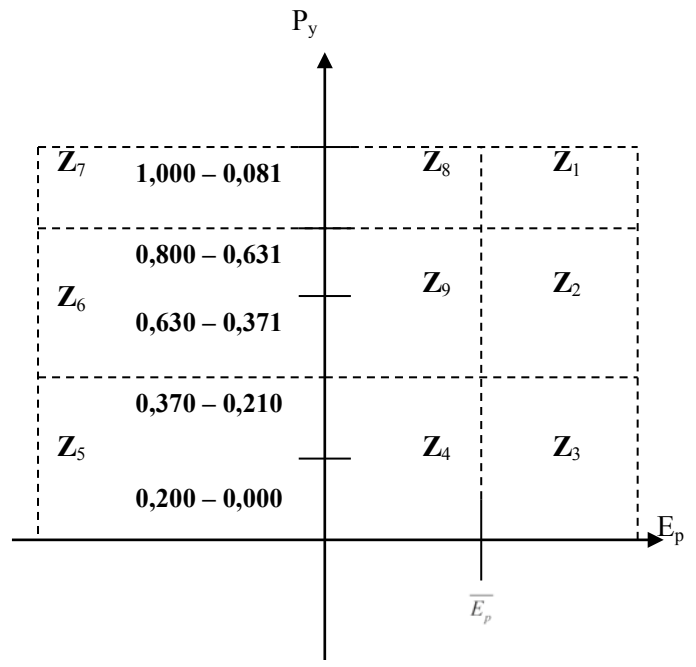

Рис. 1. Залежність між рівнем економічної ефективності ІСУП та рівнем інформаційного супроводу ІСУП

Примітки: умовні позначення: Ер - рівень економічної ефективності ІСУП; Ру - рівень інформаційного супроводу ІСУП. 
застосування заходів, націлених на покращання рівня інформаційного супроводу управлінської діяльності підприємства. Це саме стосується і випадку, коли значення $E_{p}=\overline{E_{p}}$.

У разі незастосування заходів, націлених на покращання рівня інформаційного супроводу ІСУП, високою $є$ ймовірність переходу ІСУП із зони « $\mathrm{Z}_{2} »$ у зону « $\mathrm{Z}_{3} »$. Його виявлення вимагає термінового ухвалення рішень щодо супроводу відповідності використовуваної ІСУП потребам користувачів. Ці рішення можуть зводитись до заміни застосовуваних інформаційних технологій новими, до підвищення рівня інформаційної освіти користувачів ІСУП, до реалізації організаційних змін щодо налагодження системи документообігу на підприємстві тощо. Якщо керівники підприємства неналежно здійснюють моніторинг ІСУП, зокрема факторів, які впливають на рівень іiі економічної ефективності, то ймовірно, що ІСУП із зони « $\left.\mathrm{Z}_{2}\right\rangle$ чи « $\mathrm{Z}_{3} »$ перейде у зони « $\mathrm{Z}_{9} »$ або « $\left.\mathrm{Z}_{4}\right\rangle$. У цих зонах ІСУП, окрім проблем із рівнем інформаційного супроводу, характеризується також проблемами забезпечення економічної ефективності. Щоправда, у цих зонах значення Ер є не критичним, а просто нижчим від середньоринкового рівня, що засвідчує потребу у розробленні і реалізації заходів, націлених на виявлення і використання резервів підвищення рівня економічної ефективності ІСУП.

Як бачимо з рис. 1, ІСУП, які належать до зон «Z $\mathrm{Z}_{1} »-\left\langle\mathrm{Z}_{4} »\right.$, а також до зон « $\mathrm{Z}_{8}$ » $\mathrm{i}$ « $\mathrm{Z}_{9}$ », мають порівняно прийнятний рівень економічної ефективності, проте IСУП, стан яких належить до зон « $\mathrm{Z}_{5} »-\left\langle\mathrm{Z}_{7} », \epsilon\right.$ економічно неефективними. Різниця між ними полягає лише у рівні відповідності ІСУП потребам користувачів. Так, у зоні « $\mathrm{Z}_{7} »$ можуть перебувати інтегровані системи управління, параметри яких повністю задовольняють управлінські потреби користувачів, але рівень економічної ефективності яких є нульовим або від’ємним. У зоні « $Z_{6} »$ перебувають інтегровані системи управління, які є економічно неефективними i частково не задовольняють потреб користувачів. Щодо зони « $\mathrm{Z}_{5} »$, то до неї можуть належати лише ті інтегровані системи управління, які $\epsilon$ повністю економічно неефективними, до того ж, параметри яких практично не відповідають потребам користувачів. Отже, найприйнятнішим є стан ICУП у зоні « $Z_{1} »$ і найгіршим - стан у зоні « $Z_{5} »$.

Більшість інтегрованих систем управління з проаналізованих підприємств належать до зони « $\mathrm{Z}_{4} »-13$ підприємств і зони « $\mathrm{Z}_{3} »-14$ підприємств (табл. 2). 
Результати обробки експертної інформації

\begin{tabular}{|c|c|c|c|}
\hline $\begin{array}{l}\text { Досліджувані } \\
\text { підприємства }\end{array}$ & $\begin{array}{c}\text { Рівень } \\
\text { економічної } \\
\text { ефективності } \\
\text { ІСУП }\end{array}$ & $\begin{array}{l}\text { Рівень інформаційного } \\
\text { супроводу управлінської } \\
\text { діяльності підприємства }\end{array}$ & $\begin{array}{c}\text { Зони стану } \\
\text { ІСУП }\end{array}$ \\
\hline 1 & 0,62 & 0,11 & $Z_{3}$ \\
\hline 2 & 0,56 & 0 & $\mathrm{Z}_{3}$ \\
\hline 3 & 0,54 & 0 & $Z_{3}$ \\
\hline 4 & 0,6 & 0 & $Z_{3}$ \\
\hline 5 & 0,64 & 0,13 & $Z_{3}$ \\
\hline 6 & 0,45 & 0,02 & $Z_{3}$ \\
\hline 7 & 0,42 & 0,01 & $\mathrm{Z}_{4}$ \\
\hline 8 & 0,58 & 0,11 & $Z_{3}$ \\
\hline 9 & 0,59 & 0 & $Z_{3}$ \\
\hline 10 & 0,31 & 0 & $\mathrm{Z}_{4}$ \\
\hline 11 & 0,71 & 0 & $Z_{3}$ \\
\hline 12 & 0,22 & 0 & $\mathrm{Z}_{4}$ \\
\hline 13 & 0,59 & 0,4 & $\mathrm{Z}_{2}$ \\
\hline 14 & 0,36 & 0 & $Z_{4}$ \\
\hline 15 & 0,47 & 0,32 & $Z_{3}$ \\
\hline 16 & 0,11 & 0 & $\mathrm{Z}_{4}$ \\
\hline 17 & 0,36 & 0,3 & $\mathrm{Z}_{4}$ \\
\hline 18 & 0,39 & 0,01 & $\mathrm{Z}_{4}$ \\
\hline 19 & 0,52 & 0,17 & $Z_{3}$ \\
\hline 20 & 0,34 & 0,06 & $Z_{4}$ \\
\hline 21 & 0,48 & 0,01 & $\mathrm{Z}_{3}$ \\
\hline 22 & 0,26 & 0 & $Z_{4}$ \\
\hline 23 & 0,22 & 0 & $\mathrm{Z}_{4}$ \\
\hline 24 & 0,64 & 0,12 & $Z_{3}$ \\
\hline 25 & 0,17 & 0 & $\mathrm{Z}_{4}$ \\
\hline 26 & 0,43 & 0 & $Z_{3}$ \\
\hline 27 & 0,29 & 0,2 & $\mathrm{Z}_{4}$ \\
\hline 28 & 0,37 & 0 & $\mathrm{Z}_{4}$ \\
\hline $\begin{array}{c}\text { Середні } \\
\text { значення }\end{array}$ & 0,437143 & 0,070357 & \\
\hline
\end{tabular}

Примітки: значення рівнів економічної ефективності підприємств у звітному періоді порівняно з базовим змінювалося у середньому на \pm 5.3 огляду на незначне коливання значень показників звітні дані ототожнюватимемо із базовими. 
У результаті виконаних досліджень виявлено, що 14 підприємств із загальної сукупності проаналізованих використовують інтегровані системи управління, рівень економічної ефективності яких достатньо низький, до того ж параметри цих систем лише частково задовольняють потреби користувачів. Загалом, жодна ІСУП з двадцяти восьми досліджених повністю не задовольняє потреб користувачів у повному обсязі. Отже, є усі підстави стверджувати, що актуальним завданням керівників підприємств $є$ пошук напрямів і розроблення заходів 3 підвищення рівня ефективності використовуваних ІСУП. Дослідження показали, що ІСУП доцільно оцінювати з позиції рівнів їхньої економічної ефективності і рівня інформаційного супроводу. 3 огляду на те, що мета, інструментарій та фактори, на яких грунтується оцінювання рівня економічної ефективності та оцінювання рівня інформаційного супроводу, є різними, то можливим є явище, за якого ІСУП характеризується високим рівнем економічної ефективності й одночасно низьким рівнем інформаційного супроводу. Факт виникнення такого явища виявлений під час експертного дослідження підприємств. Сукупність досліджуваних об'єктів доцільно розподілити на однорідні групи за допомогою кластерного аналізу. Ця класифікація грунтується на різних варіантах значень показників економічної ефективності використовуваних інтегрованих систем управління та інформаційного супроводу управління підприємством. Кластеризація сприятиме вимірюванню відстані між сформованими групами, яка буде основою обгрунтування доцільності дослідження факторів, які зумовили виявлений розподіл. Досліджувану сукупність об'єктів подамо у вигляді матриці із $n$ об'єктами та $m$ їхніми характеристиками, де $X_{i j}-$ значення $j$-ї характеристики для об'єкта з номером $i$ [8].

$$
X=\left(\begin{array}{lll}
x_{11} & x_{12} \ldots x_{1 j} \ldots & x_{1 m} \\
x_{21} & x_{22} \ldots x_{2 j} \ldots & x_{2 m} \\
\ldots & \ldots \ldots \ldots \ldots \ldots . . . & \ldots \\
x_{i 1} & x_{i 2} \ldots x_{i j} \ldots & x_{i m} \\
x_{n 1} & x_{n 2} \ldots x_{n j} \ldots & x_{n m}
\end{array}\right) .
$$

За допомогою даних табл. 3 (вихідна матриця), на основі використання ізоморфного групування (у групи входять об'єкти, близькі за структурою, тобто ті, в яких пропорції ознак мало відрізняються) побудуємо матрицю ізоморфних відстаней. 
Вихідна матриця

\begin{tabular}{|c|c|c|}
\hline $\begin{array}{l}\text { Досліджувані } \\
\text { підприємства }\end{array}$ & $\begin{array}{c}\text { Рівень інформаційного супроводу } \\
\text { управлінської діяльності } \\
\text { підприємства }\end{array}$ & $\begin{array}{l}\text { Рівень економічної } \\
\text { ефективності ІСУП }\end{array}$ \\
\hline 1 & 0,62 & 0,11 \\
\hline 2 & 0,56 & 0 \\
\hline 3 & 0,54 & 0 \\
\hline 4 & 0,6 & 0 \\
\hline 5 & 0,64 & 0,13 \\
\hline 6 & 0,45 & 0,02 \\
\hline 7 & 0,42 & 0,01 \\
\hline 8 & 0,58 & 0,11 \\
\hline 9 & 0,59 & 0 \\
\hline 10 & 0,31 & 0 \\
\hline 11 & 0,71 & 0 \\
\hline 12 & 0,22 & 0 \\
\hline 13 & 0,59 & 0,4 \\
\hline 14 & 0,36 & 0 \\
\hline 15 & 0,47 & 0,32 \\
\hline 16 & 0,11 & 0 \\
\hline 17 & 0,36 & 0,3 \\
\hline 18 & 0,39 & 0,01 \\
\hline 19 & 0,52 & 0,17 \\
\hline 20 & 0,34 & 0,06 \\
\hline 21 & 0,48 & 0,01 \\
\hline 22 & 0,26 & 0 \\
\hline 23 & 0,22 & 0 \\
\hline 24 & 0,64 & 0,12 \\
\hline 25 & 0,17 & 0 \\
\hline 26 & 0,43 & 0 \\
\hline 27 & 0,29 & 0,2 \\
\hline 28 & 0,37 & 0 \\
\hline
\end{tabular}

У результаті розрахунків, які здійснено за допомогою засобів кластерного аналізу у Excel, сформовано п'ять первинних ланцюжків відстаней між об'єктами і визначено відстані між ланцюжками (табл. 4). 
Таблиця 4

Матриця міжланцюжкових відстаней

\begin{tabular}{|l|c|c|c|c|c|c|}
\hline Ланцюжки & $\mathbf{L ~ 1}$ & $\mathbf{L ~ 2}$ & $\mathbf{L ~ 3}$ & $\mathbf{L ~ 4}$ & $\mathbf{L ~ 5}$ & $\mathbf{L ~ 6}$ \\
\hline L 1 & 0 & 0,739637 & 0,019461 & 0,433618 & 0,401365 & 0,405093 \\
\hline & $\mathbf{( 0 ; 0 )}$ & $(20 ; 2)$ & $(1 ; 24)$ & $(20 ; 6)$ & $(1 ; 13)$ & $(1 ; 27)$ \\
\hline L 2 & 0,739637 & 0 & 0,760989 & 0,162078 & 1 & 1 \\
\hline & $(20 ; 2)$ & $\mathbf{( 0 ; 0 )}$ & $(2 ; 24)$ & $(2 ; 21)$ & $(0 ; 0)$ & $(0 ; 0)$ \\
\hline L 3 & 0,019461 & 0,760989 & 0 & 0,45497 & 0,195226 & 0,198955 \\
\hline & $(1 ; 24)$ & $(2 ; 24)$ & $\mathbf{( 0 ; 0 )}$ & $(24 ; 6)$ & $(19 ; 13)$ & $(19 ; 27)$ \\
\hline L 4 & 0,433618 & 0,162078 & 0,45497 & 0 & 0,836874 & 0,840603 \\
\hline & $(20 ; 6)$ & $(2 ; 21)$ & $(24 ; 6)$ & $\mathbf{( 0 ; 0 )}$ & $(6 ; 13)$ & $(6 ; 27)$ \\
\hline L 5 & 0,401365 & 1 & 0,195226 & 0,836874 & 0 & 0,002799 \\
\hline & $(1 ; 13)$ & $(0 ; 0)$ & $(19 ; 13)$ & $(6 ; 13)$ & $\mathbf{( 0 ; 0 )}$ & $(15 ; 27)$ \\
\hline L 6 & 0,405093 & 1 & 0,198955 & 0,840603 & 0,002799 & 0 \\
\hline & $(1 ; 27)$ & $(0 ; 0)$ & $(19 ; 27)$ & $(6 ; 27)$ & $(15 ; 27)$ & $\mathbf{( 0 ; 0 )}$ \\
\hline $\begin{array}{l}\text { Мінімальна } \\
\text { відстань між } \\
\text { ланцюжками }\end{array}$ & 0,019461 & 0,162078 & 0,019461 & 0,162078 & 0,002799 & 0,002799 \\
\hline & $(1 ; 3)$ & $(2 ; 4)$ & $(3 ; 1)$ & $(4 ; 2)$ & $(5 ; 6)$ & $(6 ; 5)$ \\
\hline
\end{tabular}

На підставі визначених мінімальних відстаней між ланцюжками $(1 ; 3)-0,019461 ;(2 ; 4)-0,162078 ;(3 ; 1)-0,019461 ;(4 ; 2)-0,162078 ;(5 ; 6)-$ 0,$002799 ;(6 ; 5)$ - 0,002799 можна побудувати кластери. Для побудови кластерів необхідно порівняти відстані між об' єктами із критичною відстанню. Критичну відстань визначають, вибравши максимальну відстань серед мінімальних відстаней до найближчого об'єкта. У такому разі критичною $\epsilon$ відстань 0,182249. Об'єкти, відстань між якими менша від критичної, об'єднують в один кластер. Отже, із множини досліджуваних об'єктів утворилось два кластери: перший (від 1 до 27 об'єкта), другий (28 об’єкт).

Кластеризація об'єктів дає змогу систематизувати об'єкти за значеннями показників, які характеризують рівень економічної ефективності ІСУП та рівень інформаційного супроводу ІСУП, доволі складно. Кількість варіантів набуття значень оцінковими показниками залежить від специфіки використовуваної системи управління і самого підприємства. 3 огляду на це, вказані види оцінок не варто розглядати як альтернативні. Їхнє здійснення грунтується на різних цілях та інструментарії. Оцінювання інформаційного супроводу ІСУП необхідне для формування висновку про рівень виконання ІСУП покладених на неї функцій. Своєю чер- 


\section{Chapter «Economic sciences»}

гою, оцінювання рівня економічної ефективності ІСУП необхідне, щоб виявити рівень окупності вкладення коштів у розвиток цієї системи.

Важливою умовою формування належного рівня інформаційного супроводу та підвищення рівня економічної ефективності ІСУП $є$ створення автоматизованої системи моніторингу для інформування керівників підприємства про рівні інформаційного супроводу та економічної ефективності використовуваної ІСУП.

Отже, у результаті досліджень виділено два напрями удосконалення ІСУП: інформаційний супровід та економічна ефективність ІСУП. Удосконалювати ІСУП у межах першого із вказаних напрямків доцільно на предмет: підвищення рівня своєчасності і повноти реалізації цілей підприємства; підвищення рівня інформаційної освіти користувачів інформаційними технологіями та їхньої трудової дисципліни; покращання організування документоутворення і документообігу на підприємстві; супроводу наявності та відповідності використовуваної управлінської інформації та інформаційних технологій потребам користувачів тощо.

Щодо удосконалення ІСУП у межах другого із вказаних напрямів, то його доцільно здійснювати на предмет: зниження рівня ризику вкладення коштів у розвиток ІСУП; раціоналізації витрат на обслуговування використовуваної автоматизованої системи управління; збільшення джерел отримання прибутку від використання ІСУП.

\section{3. Оптимізація інтегрованої системи управління підприємством}

Оскільки ключовими параметрами ІСУП є рівень іiі економічної ефективності, а також рівень інформаційного супроводу керівників підприємства. Виконані дослідження показали, що удосконалювати ІСУП можна безперервно, проте заходи з ії удосконалення неминуче пов'язані зі зміною рівня вищевказаних параметрів. 3 огляду на це вибирати і ухвалювати управлінські рішення під час формування $\mathrm{i}$ використання ІСУП необхідно науково обгрунтовано, зокрема використовуючи економіко-математичне моделювання. Розглянемо проблему оптимізування програми розроблення і впровадження високоавтоматизованої інформаційної системи у процесі формування ІСУП за недетермінованих (необумовлених, змінних) умов. Недетермінованими вважатимемо ринкові ціни на ресурси (фінансові, матеріальні, інформаційні тощо), що необхідні для формування інтегрованої системи управління, зокрема на програмні продукти, бази даних, мережі, 
пристрої тощо, які придбані або виготовлені підприємством. Оптимальною програмою можна вважати таку, яка дає змогу отримати найбільший умовний прибуток (найбільшу економію на витратах).

У табл. 5 наведено відомі, невідомі (керовані) і некеровані параметри оптимізаційної економіко-математичної моделі [1-7].

Для супроводу коректності побудови економіко-математичної оптимізаційної моделі наведемо певні залежності та обмеження. Так, у недетермінованих умовах невідомі величини (керовані змінні), тобто ринкові ціни на ресурси і складові системи, $є$ невизначеними у межах таких діапазонів:

$$
\begin{aligned}
& o_{j}^{\min } \leq o_{j} \leq o_{j}^{\max }, \quad j=\overline{1, n} ; \\
& f_{i}^{\min } \leq f_{i} \leq f_{i}^{\max }, i=\overline{1, m} ; \\
& l_{i}^{\min } \leq l_{i} \leq l_{i}^{\max }, i=\overline{1, m} ; \\
& g_{i}^{\min } \leq g_{i} \leq g_{i}^{\max }, i=\overline{1, m} .
\end{aligned}
$$

Зважаючи на те, що одним із ключових параметрів системи є рівень іï економічної ефективності, виробниче споживання ресурсів має здійснюватись $з$ урахуванням певних нормативів витрат ресурсів та проектної кількості складових системи, які формуються власними силами підприємства:

$$
f_{i}=\sum_{j=1}^{n} t_{i j} o_{j}, i=\overline{1, m}
$$

Розглядаючи моделі оптимізування програм, як правило, зазначають, що повинен виконуватись баланс «притоку» та «відтоку» ресурсів, тобто сума обсягів наявних та закуплених (залучених) додаткових ресурсів і-го виду має дорівнювати сумі обсягів виробничого споживання та реалізації надлишку ресурсів і-го виду:

$$
b_{i}+l_{i}=f_{i}+g_{i}, \quad i=\overline{1, m} .
$$

Оскільки у дослідженні розглядається програма формування ІСУП, а не програма виробництва продукції масового споживання, то у економіко-математичній моделі оптимізуватиметься умовний прибуток підприємства, тобто економія витрат на формування інтегрованої системи, що виникає в умовах інсорсингу. Прибуток називаємо умовним, оскільки він виникає не внаслідок реалізації на ринку сформованої ІСУП, а в результаті порівняння витрат на виробництво системи із ймовірною виручкою від іiї реалізації за ринковими цінами, або їі придбання за ринковою вартістю. Отже, економія на витратах є сумою, яку підприємство зекономило, прийнявши рішення про формування IСУП в умовах інсорсингу, а не аутсорсингу: 
Таблиця 5

\section{Відомі, невідомі (керовані) і некеровані параметри моделі}

\begin{tabular}{|c|c|}
\hline $\begin{array}{c}\text { Умовні } \\
\text { позначення }\end{array}$ & Назви показників \\
\hline \multicolumn{2}{|r|}{ Відомі величини } \\
\hline$n$ & $\begin{array}{l}\text { Кількість складових системи, які повинні бути сформованими } \\
\text { підприємством в умовах інсорсингу }\end{array}$ \\
\hline$j$ & Номер окремої складової системи $(j=\overline{1, n})$ \\
\hline$m$ & Кількість видів ресурсів \\
\hline$i$ & Номер окремого виду ресурсів $(i=\overline{1, n})$ \\
\hline$t_{i j}$ & $\begin{array}{l}\text { Очікувані витрати } i \text {-го ресурсу на формування одиниці } j \text {-ї складо- } \\
\text { вої системи }\end{array}$ \\
\hline$b_{i}$ & Наявні обсяги ресурсів $i$-го виду \\
\hline$c_{j}$ & $\begin{array}{l}\text { Змінна частина витрат на формування одиниці } j \text {-ї складової сис- } \\
\text { теми, без урахування вартості спожитих ресурсів }\end{array}$ \\
\hline$o_{j}^{\min }, o_{j}^{\max }$ & $\begin{array}{l}\text { Відповідно нижня і верхня межі обсягу формування } j \text {-ї складової } \\
\text { системи }\end{array}$ \\
\hline$f_{i}^{\min }, f_{i}^{\max }$ & Відповідно нижня і верхня межі обсягу використання $i$-го ресурсу \\
\hline$l_{i}^{\min }, l_{i}^{\max }$ & $\begin{array}{l}\text { Відповідно нижня і верхня межі обсягу придбання додаткових } \\
\text { ресурсів } i \text {-го виду }\end{array}$ \\
\hline$g_{i}^{\min }, g_{i}^{\max }$ & $\begin{array}{l}\text { Відповідно нижня і верхня межі обсягу реалізації надлишку } \\
\text { ресурсів } i \text {-го виду }\end{array}$ \\
\hline \multicolumn{2}{|r|}{ Невідомі величини (керовані параметри) } \\
\hline$o_{j}$ & Обсяг формування $j$-ї складової системи \\
\hline$f_{i}$ & Обсяг виробничого споживання $i$-го ресурсу \\
\hline$l_{i}$ & Обсяг закупівлі (залучення) додаткових ресурсів $i$-го виду \\
\hline$g_{i}$ & Обсяг реалізації надлишку ресурсів $i$-го виду \\
\hline$e$ & $\begin{array}{l}\text { Умовний прибуток або економія витрат на формування системи в } \\
\text { умовах інсорсингу }\end{array}$ \\
\hline \multicolumn{2}{|r|}{ Некеровані параметри } \\
\hline$p_{j}$ & Ринкова ціна одиниці $j$-ї складової системи \\
\hline$q_{i}$ & Ринкова ціна $i$-го ресурсу \\
\hline
\end{tabular}




$$
e=\sum_{j=1}^{n} p_{j} o_{j}+\sum_{i=1}^{m} q_{i} g_{i}-\sum_{j=1}^{n} c_{j} o_{j}+\sum_{i=1}^{m} q_{i} f_{i}
$$

На підставі вищенаведених залежностей та обмежень запишемо економіко-математичну модель виробничої програми формування ІСУП упровадженням високоінтегрованої системи управління, яка належить до класу типових задач лінійного програмування [79; 90-93; $145 ; 274 ; 275 ; 277 ; 349]$ :

$$
\left.\begin{array}{l}
e=\sum_{j=1}^{n}\left(p_{j}-c_{j}\right) o_{j}-\sum_{i=1}^{m} q_{i} f_{i}+\sum_{i=1}^{m} q_{i} g_{i} \rightarrow \max , \\
\sum_{j=1}^{n} t_{i j} o_{j}-f_{i}=0, i=\overline{1, m} ; f_{i}-l_{i}+g_{i}=b_{i}, i=\overline{1, m} ; \\
o_{j}^{\min } \leq o_{j} \leq o_{j}^{\max }, j=\overline{1, n} ; f_{i}^{\min } \leq f_{i} \leq f_{i}^{\max }, i=\overline{1, m} ; \\
l_{i}^{\min } \leq l_{i} \leq l_{i}^{\max }, i=\overline{1, m} ;{ }_{i}^{\min } \leq g_{i} \leq g_{i}^{\max }, i=\overline{1, m} .
\end{array}\right\}
$$

В умовах ринкового середовища вищенаведена модель набуває практичнішого значення, якщо враховується ризик зміни ринкових цін на складові ІСУП та виробничі ресурси. Значення цих некерованих параметрів визначально впливають на значення умовного прибутку (економії витрат на формування системи). Керівники підприємств змушені ухвалювати управлінські рішення, оперуючи очікуваними ринковими цінами $\left(\overline{p_{j}}, j=\overline{1, n} ; \overline{q_{i}}, i=\overline{1, m}\right)$ та очікуваними значеннями дисперсії $\left(\sigma_{j}, j=\overline{1, n} ; \delta_{i}, i=\overline{1, m}\right)$.

Як відомо з теорії та практики менеджменту, керівників підприємств залежно від їхніх особистих якостей і частки їхнього капіталу в управлінні підприємством можна поділити на тих, які схильні до ризику (керівники, які під час формування управлінських рішень покладаються на інтуїцію, внутрішні відчуття тощо), тих, які до ризику не схильні (керівники, які формують управлінські рішення на основі перевірених, достовірних даних), а також нейтральних до ризику (керівники, які формують управлінські рішення без урахування ймовірності зміни некерованих параметрів). У разі формування рішення керівниками перших двох категорій при пошуку оптимальної виробничої програми економіко-математична модель набуває вигляду двокритеріальної задачі: 


$$
\left.\begin{array}{l}
\bar{e}=\sum_{j=1}^{n}\left(\bar{p}_{j}-c_{j}\right) o_{j}-\sum_{i=1}^{m} \bar{q}_{i} f_{i}+\sum_{i=1}^{m} \bar{q}_{i} g_{i} \rightarrow \max , \\
\sigma^{2}(e)=\sum_{j=1}^{n} \sigma_{j}^{2} o_{j}^{2}+\sum_{i=1}^{m} \delta_{i}^{2}\left(f_{i}-g_{i}\right)^{2} \rightarrow \min (\max ), \\
\sum_{j=1}^{n} t_{i j} o_{j}-f_{i}=0, i=\overline{1, m} ; f_{i}-l_{i}+g_{i}=b_{i}, i=\overline{1, m} ; \\
o_{j}^{\min } \leq o_{j} \leq o_{j}^{\max }, j=\overline{1, n} ; f_{i}^{\min } \leq f_{i} \leq f_{i}^{\max }, i=\overline{1, m} ; \\
l_{i}^{\min } \leq l_{i} \leq l_{i}^{\max }, i=\overline{1, m} ; g_{i}^{\min } \leq g_{i} \leq g_{i}^{\max }, i=\overline{1, m} .
\end{array}\right\}
$$

Як бачимо, якщо керівник схильний до ризику, то показник дисперсії умовного прибутку (економії на витратах) спрямований до максимуму, а якщо не схильний, то до мінімуму. Під час формування рішень керівниками третьої категорії пошук оптимальної виробничої програми формування ІСУП здійснюється за критерієм максимізації умовного прибутку:

$$
\begin{aligned}
& \bar{e}=\sum_{j=1}^{n}\left(\bar{p}_{j}-c_{j}\right) o_{j}-\sum_{i=1}^{m} \bar{q}_{i} f_{i}+\sum_{i=1}^{m} \bar{q}_{i} g_{i} \rightarrow \max , \\
& \sum_{j=1}^{n} t_{i j} o_{j}-f_{i}=0, i=\overline{1, m} ; f_{i}-l_{i}+g_{i}=b_{i}, i=\overline{1, m} ; \\
& o_{j}^{\min } \leq o_{j} \leq o_{j}^{\max }, \quad j=\overline{1, n} ; f_{i}^{\min } \leq f_{i} \leq f_{i}^{\max }, i=\overline{1, m} ; \\
& l_{i}^{\min } \leq l_{i} \leq l_{i}^{\max }, i=\overline{1, m} ; g_{i}^{\min } \leq g_{i} \leq g_{i}^{\max }, i=\overline{1, m} .
\end{aligned}
$$

Очікувані значення некерованих параметрів отримують здебільшого на основі застосування різних методів прогнозування. Як відомо, жодна методика не забезпечує зведення ризику виникнення помилок під час прогнозування до нуля, тому значна кількість суб'єктів господарювання віддає перевагу ухваленню рішень на підставі фактичних мінімальних і максимальних значень показників, які визначені на основі ретроспективних даних. 3 огляду на це доцільно розглянути знаходження виробничої програми за умов невизначеності некерованих параметрів. Це передбачатиме, що майбутні ціни на складові системи та виробничі ресурси можна визначити лише 3 точністю до певних діапазонів [1-7]:

$$
\begin{aligned}
& p_{j}^{\min } \leq p_{j} \leq p_{j}^{\max }, \quad j=\overline{1, n} ; \\
& q_{i}^{\min } \leq q_{i} \leq q_{i}^{\max }, i=\overline{1, m} .
\end{aligned}
$$

В. Кігель стверджує, що розв'язувати таку задачу найдоцільніше 3 використанням критерію Вальда, який забезпечує найкращий результат за найгіршої ситуації щодо некерованих параметрів [5-6]: 


$$
\min _{(p, q) \in E} e(o, f, l, g, p, q)_{\overline{(o, f, l, g) \in D}} \max
$$

де $x=\left(x_{1}, \ldots . x_{n}\right), y=\left(y_{1}, \ldots . . y_{m}\right), v=\left(v_{1}, \ldots . . v_{m}\right), w=\left(w_{1}, \ldots . . w_{m}\right)$; D-множина допустимих планів; E-множина планів, яка відповідає діапазонам можливої варіації некерованих параметрів $p=\left(p_{1}, \ldots . . p_{n}\right), q=\left(q_{1}, \ldots . . q_{m}\right)$.

Отже, оптимальною програмою підприємства із формування ІСУП можна вважати таку, яка дає змогу отримати найбільший умовний прибуток (найбільшу економію на витратах) за наявних ресурсів. Прибуток названо умовним, оскільки він виникає не внаслідок реалізації на ринку сформованої ІСУП, а в результаті порівняння витрат на створення системи із ймовірною виручкою від іiі реалізації за ринковою ціною. Отже, економія на витратах є сумою, яку підприємство зекономило, прийнявши рішення про формування ІСУП в умовах інсорсингу, а не аутсорсингу. У результаті проведених досліджень сформульовано висновок про те, що застосування на практиці такого підходу дає змогу вибрати варіант формування ІСУП із значним резервом умовного прибутку. Ці резерви керівники проектів формування, впровадження і використання ІСУП повинні розглядати через призму теорії управління активами. Тобто доцільно використовувати економіко-математичні моделі управління активами як інструмент моніторингу ІСУП.

\section{4. Висновки}

Аналізування чинних систем управління промисловими підприємствами, а також інформаційного забезпечення суб' єктів управління показало, що якісні характеристики інформації, яка лежить в основі реалізації стратегічних і тактичних цілей підприємства, визначають ефективність системи управління підприємством загалом, його економічний розвиток, конкурентоспроможність. У результаті виконаного дослідження сформовано методичні положення щодо оптимізування програми розроблення і впровадження високоавтоматизованої інформаційної системи у процесі формування ІСУП, які базуються на застосуванні економіко-математичної моделі максимізування умовного прибутку підприємства від використання ІСУП із врахуванням схильності суб'єктів управління до ризику. Практичне використання цієї моделі керівниками, системними адміністраторами, інженерами дозволить оптимізувати параметри ІСУП за етапами життєвого циклу автоматизованих інформаційних систем управ- 


\section{Chapter «Economic sciences»}

ління, досягнути вищого рівня якості управлінської інформації на вході і виході ІСУП, покращить умови для активізування креативних пошуків суб'єктів управління, дозволить трансформувати ідеї в інновації, які сприятимуть зміцненню позицій підприємства на ринку машинобудівної продукції.

\section{Список літератури:}

1. Венцель Е.С. Исследование операций. Задачи. принципы, методология / Е.С. Венцель - М.: Наука, 1988.

2. Вітлінський В.В. Аналіз та моделювання ризику проектів / В.В. Вітлінський. - К.: КДЕУ, 1995. - 17 с.

3. Вітлінський В.В. Економічний ризик і методи його вимірювання / В.В. Вітлінський, С.І. Наконечний, О.Д. Шарапов. - К.: ІЗМН, 1996. - 400 с.

4. Грабовый П.Г. Риски в современном бизнесе / П.Г. Грабовый, С.Н. Петрова, С.И. Полтавцев и др. - М.: Аланс, 1994. - 200 с.

5. Кігель В.Р. Математичні методи ринкової економіки / В.Р. Кігель. К.: Кондор, 2003. $-158 \mathrm{c}$.

6. Кігель В.Р. Методи і моделі підтримки прийняття рішень у ринковій економіці: монографія / В.Р. Кігель. - К.: ЦУЛ, 2003. - 202 с.

7. Кини Р.Л., Райфа Х. Принятие решений при многих критериях: предпочтения и замещения / Р.Л. Кини, Х. Райфа.; [пер. з англ.]; [под ред. И.Ф. Шахнова]. - М.: Радио и связь, 1981. -560 с.

8. Лапач С.Н. Статистика в науке и бизнесе / С.Н. Лапач, А.В.Чубенко, П.Н. Бабич. - К.: МОРИОН, 2002. - 640 с.

\section{References:}

1. Ventsel E.S. Yssledovanye operatsyy. Zadachy. pryntsypy, metodolohyya / E.S. Ventsel - M.: Nauka, 1988.

2. Vitlinskyy V.V. Analiz ta modelyuvannya ryzyku proektiv / V.V. Vitlinskyy. K.: KDEU, 1995. $-17 \mathrm{~s}$.

3. Vitlinskyy V.V. Ekonomichnyy ryzyk i metody yoho vymiryuvannya / V.V. Vitlinskyy, S.I. Nakonechnyy, O.D. Sharapov. - K.: IZMN, 1996. - 400 s.

4. Hrabovyy P.H. Rysky v sovremennom byznese / P.H. Hrabovyy, S.N. Petrova, S.Y. Poltavtsev y dr. - M.: Alans, 1994. -200 s.

5. Kihel V.R. Matematychni metody rynkovoyi ekonomiky / V.R. Kihel. K.: Kondor, 2003. $-158 \mathrm{~s}$.

6. Kihel V.R. Metody i modeli pidtrymky pryynyattya rishen u rynkoviy ekonomitsi: monohrafiya / V.R. Kihel. - K.: TSUL, 2003. - 202 s.

7. Kyny R.L., Rayfa K.H. Prynyatye reshenyy pry mnohykh kryteryyakh: predpochtenyya y zameshchenyya / R.L. Kyny, K.H. Rayfa; [per. z anhl.]; [pod red. Y.F. Shakhnova.]. - M.: Radyo y svyaz, 1981. - 560 s.

8. Lapach S.N. Statistika v nauke i biznese / S.N. Lapach, A.V. Chubenko, P.N. Babich. - K.: MORION, 2002. -640 s. 